\title{
Maturation of Thyriothecia of Schizothyrium pomi on the Reservoir Host Rubus allegheniensis
}

\author{
Daniel R. Cooley, Associate Professor, Susan M. Lerner, Research Associate, and Arthur F. Tuttle, Extension \\ Educator, Department of Plant, Soil, and Insect Sciences, University of Massachusetts, Amherst 01003
}

\begin{abstract}
Cooley, D. R., Lerner, S. M., and Tuttle, A. F. 2007. Maturation of thyriothecia of Schizothyrium pomi on the reservoir host Rubus allegheniensis. Plant Dis. 91:136-141.

Flyspeck disease caused by the Ascomycete fungus Schizothyrium pomi is a major component of a summer disease complex that has become an increasing problem on apple in the northeastern United States. This study describes the development of thyriothecia of $S$. pomi on one of its major reservoir hosts, wild blackberry, and suggests that temperature drives thyriothecium maturation. An empirical model relating thyriothecium maturity to degree-days from apple leaf budbreak in Massachusetts had a high coefficient of determination, $R^{2}=0.90$. Ninety percent of thyriothecia matured between 540 and 1,625 degree-days from the budbreak biofix. S. pomi produced one generation of asci per year on blackberry. This discrete maturation period occurred well before signs of disease developed on apple fruit and before production of conidia. Considering that fungicide applications for scab management in commercial apple orchards also will protect fruit from flyspeck during early fruit development, it is unlikely that ascospores produced on reservoir hosts directly infect fruit. Instead, they probably initiate infections in reservoir hosts adjacent to commercial orchards, which produce conidia that are the inoculum which infects apple fruit in commercial production.
\end{abstract}

Additional keywords: epidemiology, sooty blotch, Zygophiala jamaicensis

Flyspeck disease of apple is an increasingly significant problem in commercial orchards in the eastern United States $(10,21,24)$. Flyspeck commonly occurs on apple fruit in association with another disease, sooty blotch; both diseases are limited to the fruit cuticle, causing minimal physical damage but producing unsightly blemishes that significantly reduce fruit value. In Massachusetts, the attempt to prevent losses from this summer disease complex causes producers to apply 35 to $40 \%$ of the fungicides used on commercial apple (9). These fungicide applications are timed largely on a calendar basis, because the epidemiology and etiology of the disease complex are not well understood. The generally accepted causal agent of flyspeck is the fungus Schizothyrium pomi (Mont. \& Fr.) Arx (anamorph Zygophiala jamaicensis E. Mason). Sooty blotch is caused by several fungi, including Peltaster fructicola Johnson, Leptodontidium elatius (G. Mangenot) De Hoog, and Geas-

Corresponding author: D. R. Cooley

E-mail: dcooley@ microbio.umass.edu

Accepted for publication 11 September 2006.

DOI: 10.1094/PDIS-91-2-0136

(C) 2007 The American Phytopathological Society trumia polystigmatis Batista \& M. L. Farr (14). However, recent analysis of the internal transcriber spacer and large subunit regions of ribosomal DNA from Midwestern U.S. and Chinese isolates of flyspeck and sooty blotch fungi indicate that species diversity in the complex is much larger, including fungi from the genera Dissoconium, Mycosphaerella, Pseudocercosporella, Colletogleum, and Xenostigmina $(1,6)$. Although the etiology of this disease complex involves several fungi, flyspeck is the disease most frequently observed and most difficult to manage in commercial orchards in Massachusetts (9), and the fungus causing flyspeck in Massachusetts has been identified consistently as S. pomi. This study has focused on $S$. pomi as a critical component in management of the summer disease complex on apple in Massachusetts.

Williamson and Sutton (24) reviewed the epidemiology of flyspeck. The disease is characterized by the growth of circular, black, epicuticular thyriothecia on the waxy surfaces of many plants. These thyriothecia, individually approximately 0.25 $\mathrm{mm}$ diameter, appear as colonies that are 1 to $3 \mathrm{~cm}$ in diameter (24), giving the disease its name. The fungus overwinters as thyriothecia on cuticle tissue of perennial hosts in sites along orchard borders $(2,3,11,12,17,18,21,23)$. A portion of these thyriothecia will produce ascospores during spring and early summer (16). Common blackberry (Rubus allegheniensis Porter) is a reservoir host supporting $S$. pomi thyriothecia, and is a good model host on which to study the life history of the fungus. The primary objectives of this study were to determine when $S$. pomi produces ascospores within its life cycle and relative to the phenology of the apple host, and whether ascospore production in $S$. pomi is related to environmental factors, particularly temperature.

\section{MATERIALS AND METHODS}

Thyriothecium maturation. Squash mounts of $S$. pomi thyriothecia were prepared as follows. Wild blackberry floricanes with thyriothecia were collected from several sites adjacent to commercial orchards in Massachusetts and returned to the laboratory. The canes were cut into segments approximately $5 \mathrm{~cm}$ long. Each cane segment was placed on the stage of a dissecting microscope $(\times 25)$, the tip of a fine dissecting needle was placed on the cane surface, and the thyriothecium nearest the tip was removed gently using a scalpel or dissecting needle. Each thyriothecium was immediately placed in a drop of lactic acid/glycerol solution containing aniline blue $(20 \mathrm{ml}$ of lactic acid, $40 \mathrm{ml}$ of glycerol, and $0.05 \mathrm{~g}$ of aniline blue in $200 \mathrm{ml}$ of distilled water). A coverslip was placed over the thyriothecium, and gentle pressure was applied to it with the wooden handle of a dissecting needle in order to break the ascocarp wall. The thyriothecium then was observed using phase contrast microscopy under low-power magnification $(\times 200)$. Thyriothecia were rated according to the following maturity classes: undeveloped (no asci present $)=0$, immature asci present without ascospores $=1$, mature asci present containing ascospores $=2$, and majority of asci ruptured or empty $=3$ (Fig. 1).

Beginning on 12 May 1997, blackberry canes from two sites, Shelburne and Sterling, MA, were sampled to evaluate maturation of thyriothecia in situ. At 6- to 10day intervals, five floricanes from each site were selected arbitrarily, brought to the laboratory, and 10 thyriothecia per cane were examined for maturation. Sampling stopped when thyriothecia were no longer 
producing mature ascospores. Similarly, in 1998, thyriothecia were evaluated for three sites in Ashfield, Belchertown, and Brimfield, MA and, in 1999, for four sites in Ashfield, Belchertown, Brimfield, and Shelburne, MA. Temperatures at the sites were monitored using computerized dataloggers (CR10X; Campbell Scientific, Inc., Logan, UT) or mechanical recording hygrothermographs (WeatherMeasure Corp., Sacramento, CA). At sites where dataloggers were used, relative humidity $(\mathrm{RH})$ data also were obtained using sensors that recorded both temperature and $\mathrm{RH}$ (Model HMP45C; Campbell Scientific, Inc.). These sensors were tested and calibrated each year by the manufacturers. Sensors were placed with weather stations on open, grass-covered sites at orchards, up to $1 \mathrm{~km}$ from areas where canes were sampled. Temperature data were available from all sites in all years for a total of nine data sets, whereas only five full sets of RH data were available.

Accumulated hours of leaf wetness were measured at the Cold Spring Orchard Research and Education Center in Belchertown, MA with an electronic leaf wetness sensor (model 237; Campbell Scientific, Inc.) coated with latex paint. Sensors were in the same location during 1998 and 1999, at a monitoring station $10 \mathrm{~m}$ from trees and mounted $1.5 \mathrm{~m}$ from the ground at an approximately $45^{\circ}$ angle facing north.

Trapping conidia. To determine how maturation of $S$. pomi thyriothecia relates to other aspects of the life history of the fungus, $Z$. jamaicensis conidia were trapped at one site in each year, using Rotorod samplers (Sampling Technologies, Minnetonka, MN). Three units were placed approximately $5 \mathrm{~m}$ apart within the blackberry plants, and three more units were placed approximately $5 \mathrm{~m}$ apart along the orchard border on metal poles at a height of $0.8 \mathrm{~m}$. The units were run over a 24-h period using intervals of $180 \mathrm{~s}$ on and $1,120 \mathrm{~s}$ off. After the 24-h period, sampling rods were removed from the unit, stained with aniline blue, and examined under a compound microscope at $\times 200$. All $Z$. jamaicensis conidia on one side of a rod were counted. In 1997, conidia were sampled on 13 dates, at intervals of 7 to 14 days, starting 11 June and ending 17 September. In 1998, trapping was done on 10 dates beginning 1 June and ending $25 \mathrm{Au}-$ gust. In 1999, conidia were trapped on 11 dates, beginning 19 June and ending 3 September.

Empirical degree-day model of thyriothecia development on blackberry. To evaluate temperature effects on thyriothecium development, degree-days (DD) for each site and each year were estimated using daily minimum and maximum temperatures and a single sine transformation (4). The most likely application of a model relating DD to $S$. pomi development would be to manage flyspeck on commercial apple; therefore, a biofix was established relative to apple trees growing in orchards immediately adjacent to the blackberry plants. The biofix was the date on which $50 \%$ of the fruiting buds on the apple cv. McIntosh showed green tissue.

For each site in each year, the numbers of thyriothecia that were mature (maturity class 2) out of the 50 sampled at each site were summed to give the total accumulated mature thyriothecia for that site in that year. The accumulated percentage of mature thyriothecia $\left(\mathrm{P}_{\mathrm{M}}\right)$ for each date at each site in each year then was calculated by taking the sum of thyriothecia at maturity class 2 to that date and dividing by the accumulated mature thyriothecia for that site in that year. The $\mathrm{P}_{\mathrm{M}}$ for each sampling date was plotted as a function of DD accumulated by that date.

To determine the most appropriate base temperature to use in calculation of DD for each orchard in each year, 11 sets of DD data were calculated for different base temperatures at $1^{\circ} \mathrm{C}$ intervals from 0 to $10^{\circ} \mathrm{C}$. The $\mathrm{P}_{\mathrm{M}}$ for each orchard on each date was graphed as functions of DD accumulated at each base temperature. The functions were fit to a logistic curve of the general form $\mathrm{P}_{\mathrm{M}}=100 /(1+\beta[\exp (-\mathrm{DD}[r])])$, where $P_{M}$ is the accumulated percent mature thyriothecia, DD is accumulated de-
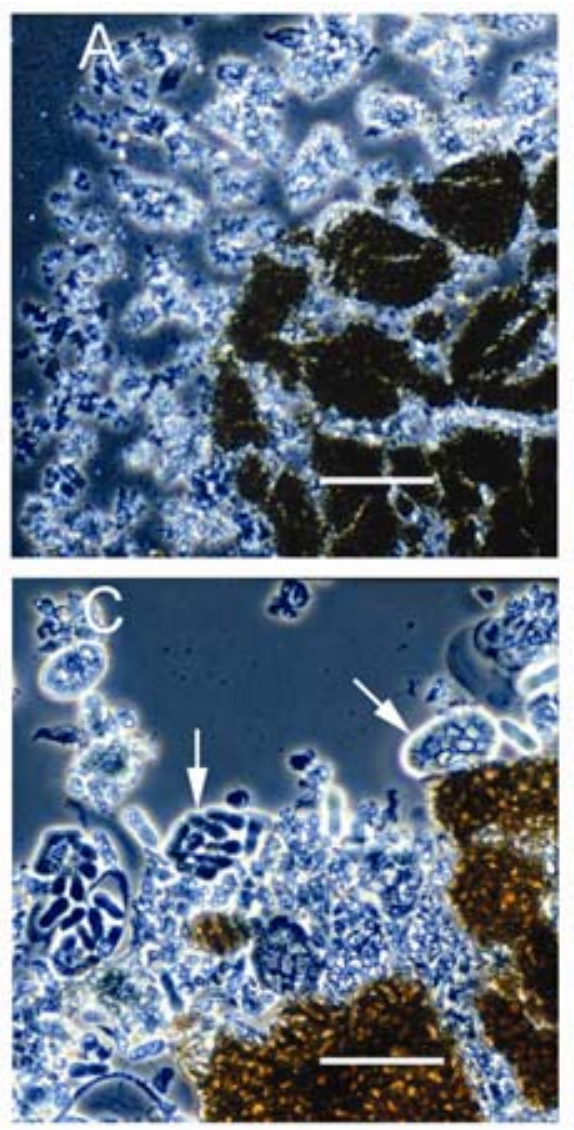

Fig. 1. Examples of squash mounts of Schizothyrium pomi thyriothecia demonstrating the four maturity classes. Bars $=30 \mu \mathrm{m}$. A, No asci, undifferentiated ascostroma, maturity class $=0$. B, Immature asci (indicated by arrows) without ascospores, maturity class $=1$. C, Mature asci (indicated by arrows) containing ascospores, maturity class $=2$. D, Empty asci (indicated by arrows), maturity class $=3$.
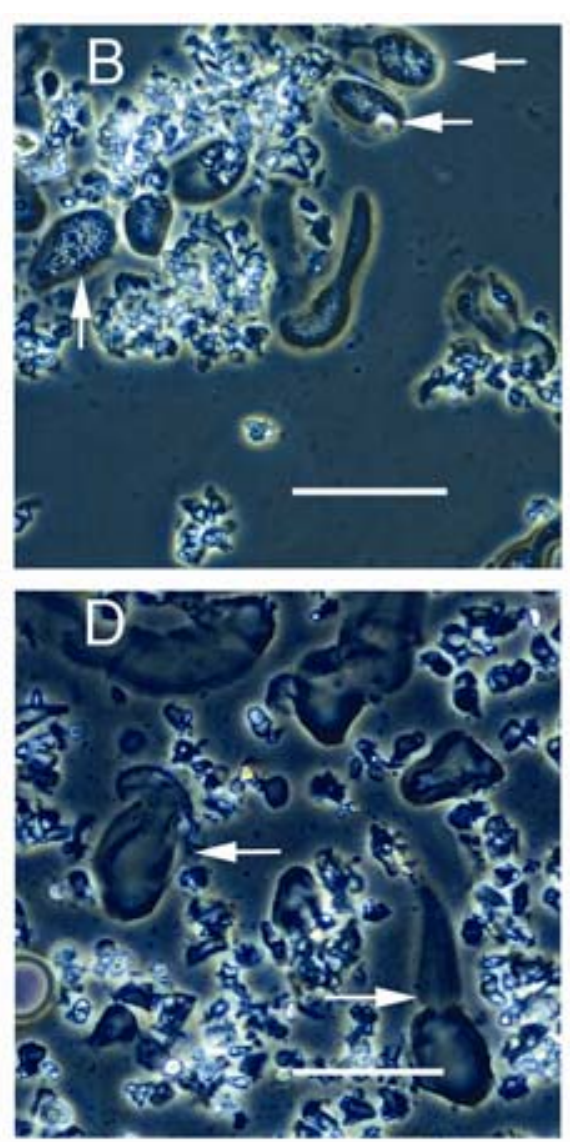

gree days, and $\beta$ and $r$ are parameters of the logistic curve. Accumulated percent mature thyriothecia $\left(\mathrm{P}_{\mathrm{M}}\right)$ is calculated as a percentage of only those thyriothecia that produce mature spores. Parameters were estimated using the Gauss-Newton iteration method with step halving in the data analysis software package JMP 4 (SAS Institute Inc., Cary, NC). Confidence intervals at $P=0.05$ were calculated for the parameters using profile likelihood confidence intervals (5).

Because $S$. pomi normally grows only at $\mathrm{RH} \geq 95 \%$ (19), DD values for the orchard sites were calculated for those periods when $\mathrm{RH} \geq 95 \%\left(\mathrm{DD}_{\mathrm{RH} \geq 95}\right)$. The $\mathrm{DD}$ values for each hour were summed for each day and divided by 24 , because the periods where $\mathrm{RH} \geq 95 \%$ frequently were less than a full day. Five of the nine data sets had hourly humidity data sufficient to calculate $\mathrm{DD}_{\mathrm{RH} \geq 95}$. Curves were calculated using $\mathrm{DD}_{\mathrm{RH} \geq 95}$ and with DD at the same sites.

Thyriothecium development in the field during summer and autumn. New $R$. allegheniensis primocane stems were sampled during summer and autumn of 1998 and 1999 and examined to determine when thyriothecia formation occurred. In 1998, sampling at two sites, Belchertown and Brimfield, MA, began on 2 July and continued to 24 September. In 1999, sam-

Plant Disease / February 2007 
pling began on 21 July and continued until 11 October at four sites: Ashfield, Belchertown, Brimfield, and Shelburne, MA. At each site in each year, 10 primocanes were selected arbitrarily and flagged. On six sampling dates in each year, at 2- to 4week intervals, segments of cane were collected and the number of thyriothecia on the first meter of each cane from the ground was counted. Segments of cane with thyriothecia also were collected from five canes in the immediately adjacent area. These cane segments were brought back to the laboratory and thyriothecia sampled and examined for maturation as described above.

Least squares analysis of variance was performed on the thryriothecium counts using site and year as main effects (JMP 4 ), and linear regressions of the mean number of thyriothecia per cane as a function of date for each site were calculated (DeltaGraph).

Thyriothecium development in the field in winter and early spring. Earlier studies (16) had shown that thyriothecia on

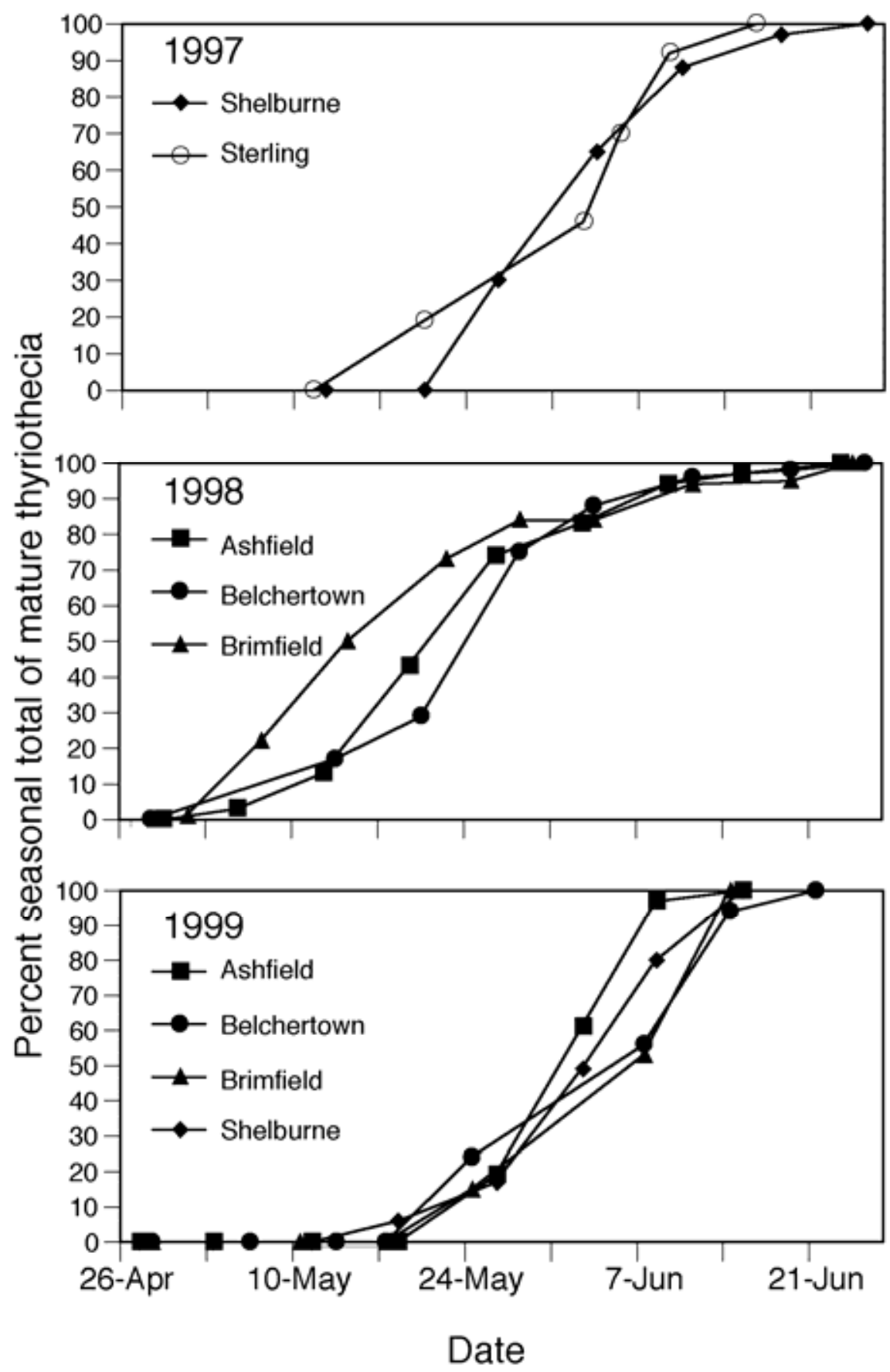

Fig. 2. Percent thyriothecia on blackberry canes that have matured during each year (1997, 1998, and 1999) in five Massachusetts sites (Ashfield, Belchertown, Brimfield, Shelburne, and Sterling). The percentage is calculated based on thyriothecia that reach maturity. Approximate phenological development stages, initiation of bloom and end of petal fall, of 'McIntosh' apple trees adjacent to canes are indicated by B and PF, respectively. blackberry canes sampled in the field during late winter and early spring could be stimulated to produce mature ascospores within 1 week when incubated at $100 \%$ humidity and $21^{\circ} \mathrm{C}$ using Parafilm-sealed petri dishes containing moistened filter paper as moist chambers. In order to determine when thyriothecia develop the potential to mature in laboratory incubations, thyriothecia on blackberry floricanes from three sites in Massachusetts were collected monthly from December 1996 to April 1997. Segments were removed from five floricanes at each site. These segments were incubated in moist chambers for 1 week as described above. After incubation, five arbitrarily selected thyriothecia were examined from each cane from each site to determine maturity. Linear regressions of the percent thyriothecia producing mature asci as a function of date were calculated (DeltaGraph).

\section{RESULTS}

Thyriothecium maturation. Thyriothecia on blackberry canes developed in a consistent pattern over the 3 years and five orchard sites in the study. Graphs of percentage of the seasonal total of mature thyriothecia as a function of date had a sigmoid pattern (Fig. 2). Initial observations of mature spores varied by site, occurring from 20 to 26 May 1997, 1 to 5 May 1998, and 18 to 26 May 1999. Similarly, the date at which maturation of thyriothecia reached $95 \%$ varied by site and year, from 16 to 18 June 1997,8 to 19 June 1998, and 8 to 13 June 1999.

Many thyriothecia were rated at maturity class 0 (Fig. 1A), even at the end of the maturation periods. These thyriothecia never developed asci. During periods when $\mathrm{P}_{\mathrm{M}} \geq 95 \%$, the number of thyriothecia rated 0 varied from 33 to $69 \%$.

Trapping conidia. The first observation of conidia on traps in each year occurred in mid-July (Table 1). There was no overlap between the periods of ascospore maturation and the beginning of conidial production. Production of the ascospores and conidia was separated by approximately 3 to 4 weeks. The time from the first production of ascospores to trapping of the first conidia was approximately 6 to 9 weeks.

Empirical DD model of thyriothecia development on blackberry. When $\mathrm{P}_{M}$ was fit as a logistic function of DD at various base temperatures, the best fit was for $\mathrm{DD}_{0}$, where $R^{2}=0.90$ (Fig. 3). The resulting equation had the following parameters and coefficients: $P_{M}=100 /(1+347 \times$ [Exp $(-\mathrm{DD} \times 0.0054)])$.

The equation predicted that $5 \%$ of the thyriothecia would mature at $540 \mathrm{DD}_{0}$ and $95 \%$ would mature by $1,630 \mathrm{DD}_{0}$. The first mature spores actually were observed at $550 \mathrm{DD}_{0}$ and no spores were observed beyond 2,100 $\mathrm{DD}_{0}$.

Limiting $\mathrm{DD}_{0}$ accumulation to periods of high humidity did not improve the fit of 
the logistic equation predicting $\mathrm{P}_{\mathrm{M}}$ and the resulting equation had a relatively low coefficient of determination, $R^{2}=0.48$. For comparison, using total $\mathrm{DD}_{0}$ for the same set of orchards and years, $R^{2}=0.85$. Over the entire period, heat units alone, rather than heat units only during periods of high $\mathrm{RH}$, provided the better predictor of thyriothecium maturity.

Thyriothecium development in the field during summer and autumn. The fungal stroma that would become thyriothecia began to be visible on blackberry primocanes in mid- to late summer, and continued to form until late fall. In 1998, a few thyriothecia were visible on canes at both sites on 2 July (data not shown). Flyspeck signs on nonsprayed apple fruit adjacent to these sites first appeared on 16 to 27 July. In 1999, no thyriothecia were visible on new primocanes of $R$. allegheniensis on 19 July (Fig. 4). On 21 August, all sites had blackberry canes with visible thyriothecia. Flyspeck signs on nonsprayed apple fruit adjacent to these sites first appeared from 15 to 21 September.

In both years, the number of thyriothecia per cane generally increased through to the end of sampling. Both site and date effects were significant and there was a significant interaction between site and date in both years $(P \leq 0.01)$. Linear regressions of the number of thyriothecia per cane as a function of date were significant, with positive slopes. Coefficients of determination for regressions at each site in each year ranged from 0.79 to 0.92 . All incubated thyriothecia collected from these canes over both years failed to produce mature asci.

Thyriothecium development in the field in winter and early spring. Thyriothecia differed in their maturation following high-humidity incubation, depending on the date they were collected and on the site where they grew. Thyriothecia collected from three sites in Massachusetts during December 1996 failed to develop after 1 week of incubation in high humidity at $21^{\circ} \mathrm{C}$ (Fig. 5). Of thyriothecia collected from the same sites in January 1997, 4 to $13 \%$, depending on site, developed mature asci after incubation. The percentage that matured in subsequent samples generally increased through April 1997. Analysis of variance showed that both date and site were significant factors $(P \leq 0.05)$.

\section{DISCUSSION}

S. pomi causes an economically important disease of apple, yet much of the epi-

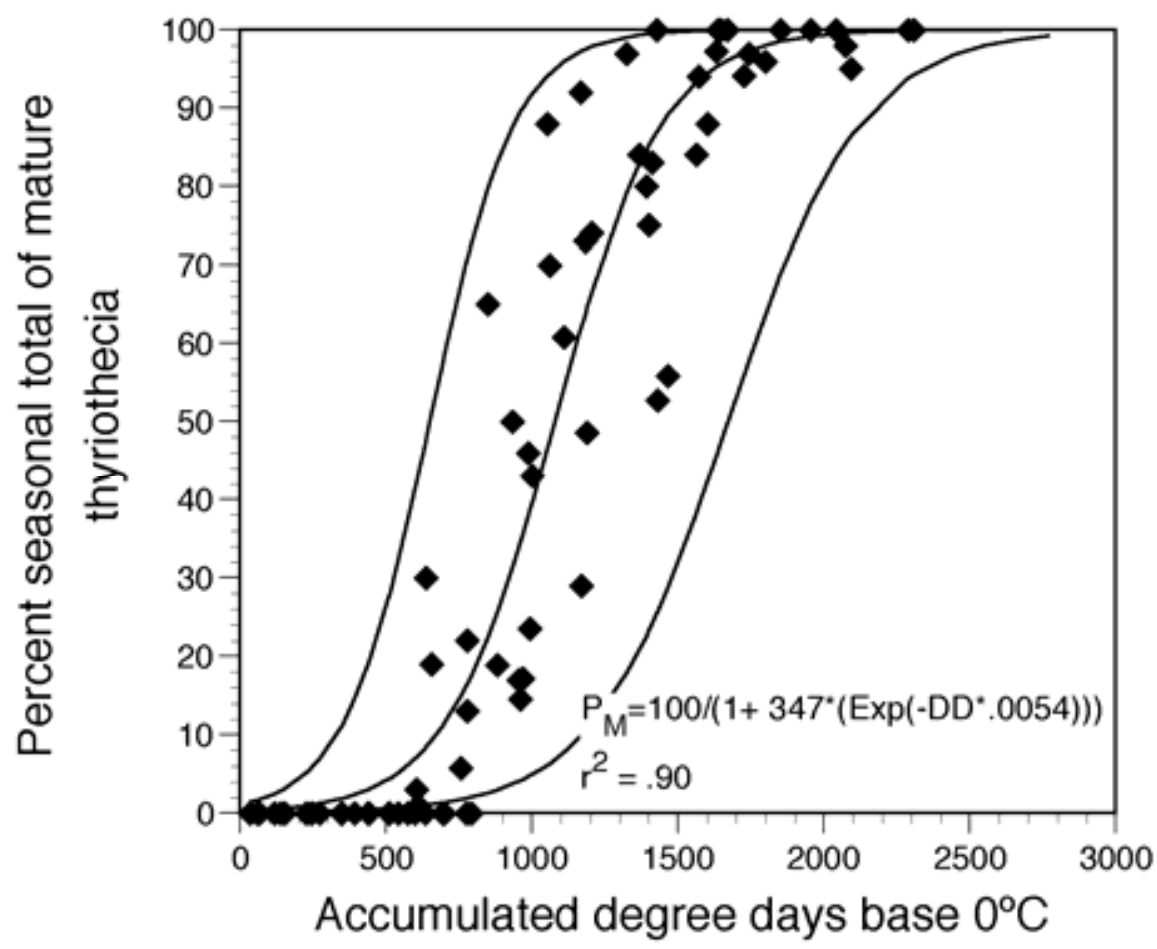

Fig. 3. Percentage of the season's thyriothecia matured in five Massachusetts sites during 1997, 1998, and 1999 as a function of the degree days (base $0^{\circ} \mathrm{C}$ ) accumulated from the green tip for the apple cv. McIntosh growing in orchards adjacent to the sampling site. The function is $P_{M}=100 /(1+347$ $[\operatorname{Exp}(-\mathrm{DD}[0.0054])]), r^{2}=0.90$, and is bounded by $95 \%$ confidence intervals.

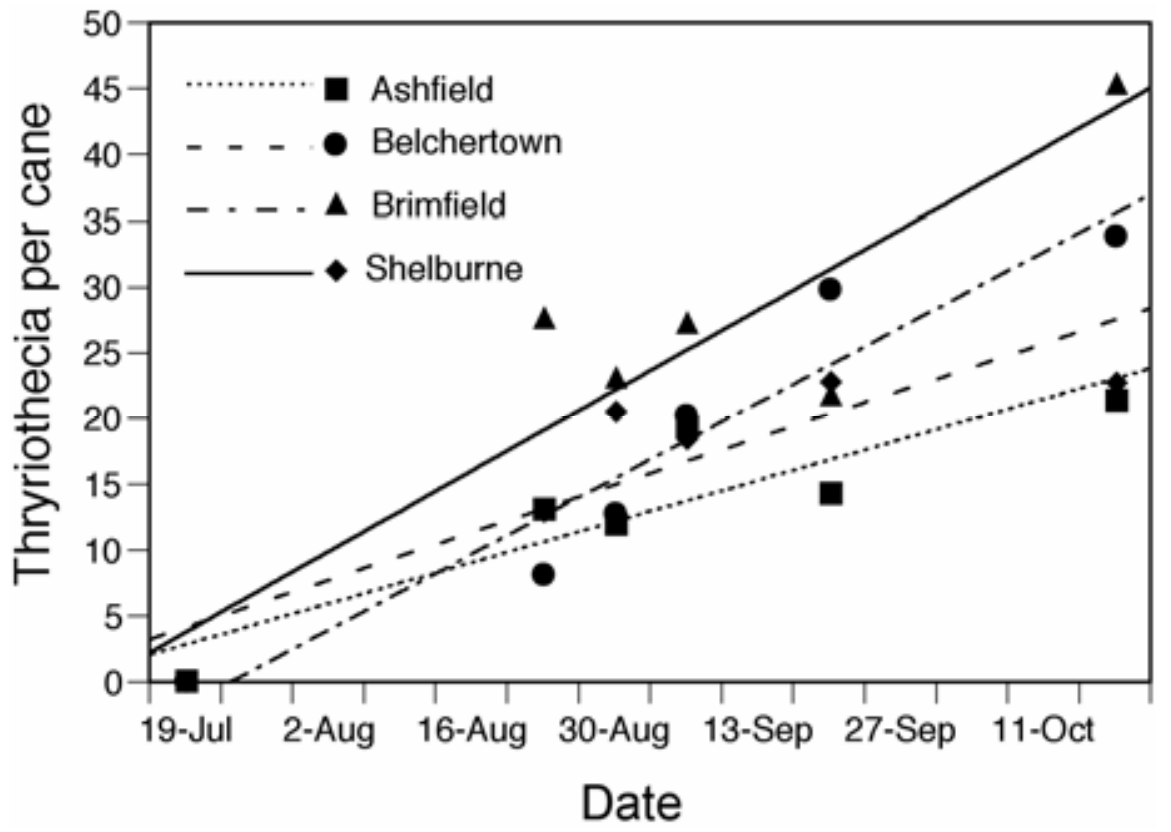

Fig. 4. Thyriothecia counts per cane from Rubus allegheniensis growing in sites bordering four apple orchards during 1999 in Massachusetts (Ashfield, Belchertown, Brimfield, and Shelburne). Ten canes located in a flagged area of each site were counted on each date. Lines represent the linear regressions for each location.

Table 1. Beginning and end of Schizothyrium pomi ascospore production compared with the first captures of Zygophiala jamaicensis conidia on Rotorod traps over 3 years

\begin{tabular}{lccccc}
\hline Site, year & $\begin{array}{c}\text { First ascospores } \\
\text { produced }\end{array}$ & $\begin{array}{c}\text { Last ascospores } \\
\text { produced }\end{array}$ & $\begin{array}{c}\text { First conidia } \\
\text { trapped }\end{array}$ & $\begin{array}{c}\text { Days from first } \\
\text { ascospores to conidia }\end{array}$ & $\begin{array}{c}\text { Days from last } \\
\text { ascospores to conidia }\end{array}$ \\
\hline Shelburne, 1997 & 26 May & 18 June & 11 July & 45 & 23 \\
Ashfield, 1998 & 5 May & 22 June & 14 July & 69 & 22 \\
Shelburne, 1999 & 18 May & 14 June & 12 July & 54 & 28 \\
\hline
\end{tabular}


demiology relevant to apple infections ing in borders along the edge of commercial orchards. Although thyriothecia have been found on apple twigs and fallen fruit in orchards $(12,21)$, it is unlikely that these serve as important sources of primary inoculum in commercial situations where fungicides commonly are used. Sutton (22) has suggested that reservoir hosts are the inoculum source for flyspeck of apple. Therefore, it would be useful to know when such inoculum is produced and what form it takes, and relate inoculum development to flyspeck infections on commercial apple. Flyspeck epidemics on reservoir hosts have significant economic relevance only inasmuch as those epidemics move into commercial orchards; hence, the development of $S$. pomi was studied with reference to apple phenology.

A previous study of $S$. pomi development on blackberry (16) indicated that thyriothecia develop in two stages: first, the thyriothecial stroma matures to a point where ascogenous hyphae are produced; then, asci mature and ascospores are released. Numbers of thyriothecia increase during summer and fall, but do not develop the ability to produce ascospores until January. The proportion of thyriothecia that can mature under laboratory incubation increases from winter into spring. In Massachusetts, thyriothecia mature in the field by May. These mature thyriothecia after which maturation stops and no more ascospores are produced.

Maturation on the blackberry host occurs during a period when green tissue is first produced on apple fruit, and continues apparently occurs on reservoir hosts growcan release ascospores for 4 to 6 weeks,

to a point when apple fruit are approximately 2 to $4 \mathrm{~cm}$ in diameter. In this study, the end of the production of primary inoculum had occurred by mid- to late June in Massachusetts. Although the beginning and end of ascospore production generally coincided with apple phenology, dates varied from year to year. For example, depending on the orchard and year, maturation began as early as 5 May and as late as 25 May. This variability would be expected when a process is highly dependent on temperature and would be expected to coincide with plant phenology. The log phase of ascospore maturation coincides with the petal fall stage of growth on adjacent apple hosts, and ascospore production ended 3 to 4 weeks after petal fall.

The first flyspeck colonies on apple fruit became visible on 16 July and as late as 21 September, approximately 30 to 90 days, respectively, after the end of ascospore production. The earliest flyspeck signs appear on apple by mid-July in Massachusetts, though they develop earlier in warmer climates: near the end of June in West Virginia (13), by late May or early June in North Carolina (7), and by the beginning of May in Alabama (15). If maturation of the initial inoculum for flyspeck epidemics is driven largely by temperature, earlier appearance of thyriothecia in the south would be expected.

The first flyspeck signs on apple appeared after the first thyriothecia were observed on blackberry. In 1998, thyriothecia appeared relatively early and were observed on blackberry at the first sampling in early July, with signs on apple developing at the same sites by late July. In

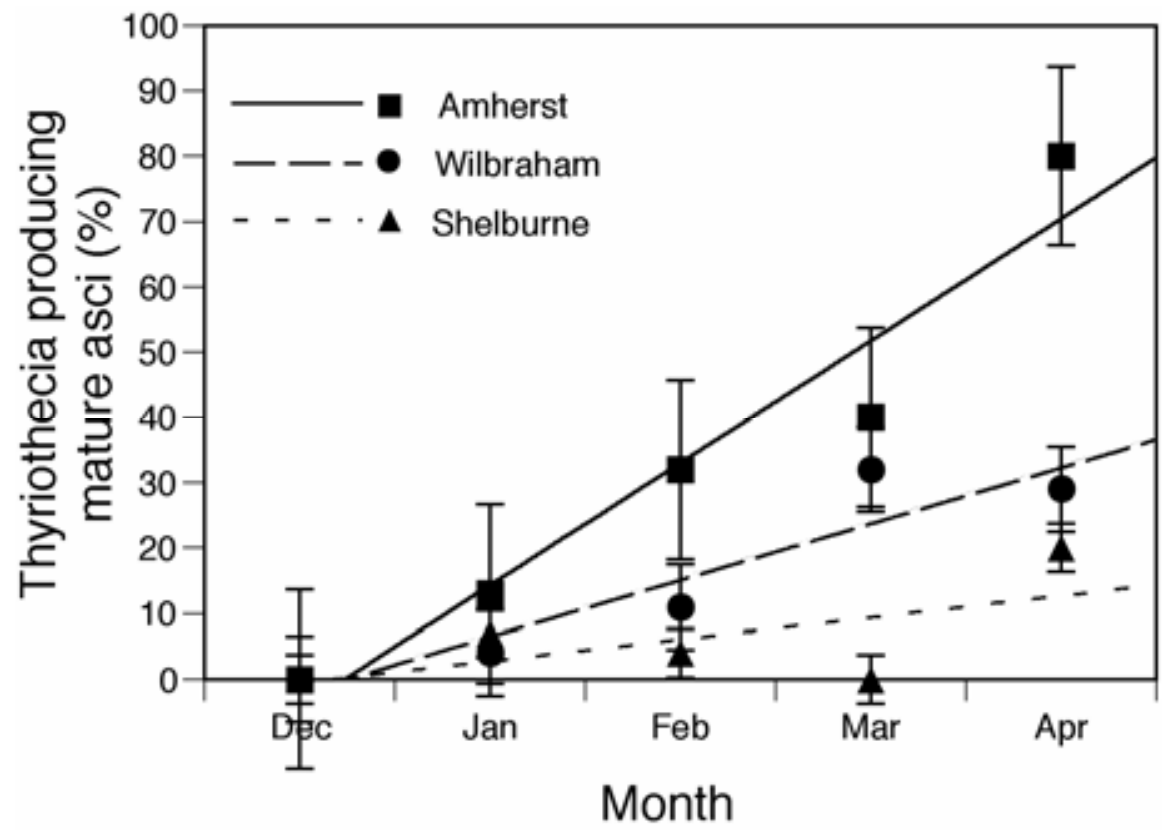

Fig. 5. Percentage of thyriothecia that had produced mature asci after 1 week incubation at $21^{\circ} \mathrm{C}$ under high humidity. Collections were from blackberry canes at three sites in Massachusetts (Amherst, Wilbraham, and Shelburne) during 1996-97. Lines indicate linear regressions for each site, and vertical lines indicate standard errors for points within each site.
1999, thyriothecia first appeared on blackberry canes by mid-August and on apple in early September. This may indicate that the environment in orchard hedgerows is more conducive to $S$. pomi growth, or that the infections on these canes occurred before those on adjacent apple trees because the source of inoculum was closer to the blackberry plants than to the apple trees. The difference between the 2 years was reflected in differences in wetting hours. Accumulated hours of leaf wetness at Belchertown, MA reached $270 \mathrm{~h}$ on 8 July 1998 and 22 August 1999, respectively, indicating that leaf wetness duration was markedly different in the 2 years. In addition, although leaf wetness undoubtedly varied between observation sites in each year, the first appearance of flyspeck on unprotected apple fruit at the sites occurred within 1 to 2 weeks after 270 accumulated leaf wet hours at Belchertown, as would be predicted by the North Carolina flyspeck model (8).

The large number of thyriothecia rated 0 after periods of incubation or during peak maturation on blackberry in the field suggests that not all thyriothecia were fertile. Thyriothecia that have produced and released ascospores would have been cracked in the release process, and the content of thyriothecia that produced asci was less dense than that in thyriothecia that did not produce asci. It is not clear why significant numbers of thyriothecia failed to develop. Possibly, after ascostroma form they do not have an appropriate sexual stimulus to complete the maturation process. This study and other observations (16) suggest that thyriothecia of $S$. pomi form before sexual hyphae develop, and that some lag time occurs between the formation of ascostroma and subsequent development of asci. If sexual hyphae fail to develop, or different mating types do not contact each other, ascostroma cannot develop asci.

$S$. pomi thyriothecia formed during the growing season never produced ascospores without overwintering. This suggests that formation of sexual spores may involve low-temperature dormancy. Such a requirement would be puzzling, because $S$. pomi is known to grow on plants in tropical climates (3). However, in order to grow in temperate climates, the fungus would need a mechanism for dormancy during cold periods that delays formation and release of ascospores until ascospores can germinate safely. Given recent studies suggesting that fungi forming flyspeck signs are more diverse than originally thought (6), it is possible that putative tropical Schizothyrium spp. differ taxonomically from Schizothyrium spp. in temperate climates. The rate at which maturation of ascospores progressed depended on the collection site. The rate of development of new thyriothecia on blackberry primocanes also differed by site. 
Although these studies provide a clearer understanding of the timing of maturation of $S$. pomi thyriothecia, the role of ascospores in direct infection of apple remains unresolved. Apple inoculated with ascospores from several wild hosts can cause flyspeck signs (2,3). However, conidia of $Z$. jamaicensis commonly infect apple and cause flyspeck $(2,11,19)$. Spore trapping and the timing of the development of flyspeck signs also indicated that conidia are a significant portion of the inoculum that causes flyspeck on apple (22). Conidia are common during the period of most rapid symptom development. The period between the end of ascospore release and the first appearance of flyspeck on apple was 60 to 90 days. Conidia were trapped 22 to 28 days after the last ascospores were produced, and 45 to 54 days after the first ascospores were produced (Table 1). Ascospore production ended during a time when commercial growers are still applying fungicides to manage apple scab. These fungicides would control infections from S. pomi ascospores that enter the orchard. It is unlikely that ascospores do any more than initiate flyspeck epidemics in reservoir hosts, producing infections on reservoir plants, which then produce conidia. Epidemics build in the reservoir plants and, where they are adjacent to commercial apple trees, conidia are blown into orchards where they cause infections on fruit.

Commercial apple fruit are essentially a dead-end host for $S$. pomi. Thyriothecia formed on fruit and twigs will be removed with harvest or killed by fungicides applied before they mature in spring. Natural epidemics of flyspeck cycle in reservoir hosts, economically unimportant except where they provide inoculum that can blemish apple fruit. Knowing when and where this inoculum is produced can help in the development of effective and ecologically sound management techniques for flyspeck. For example, combining knowledge of how long fungicide applications are effective (20) with the timing of conidial production and migration to orchards provides such a tool. It may be possible to adapt a model that has associated infections with 270 accumulated wetting hours after petal fall $(1,8)$ to better time fungicide applications with spore production. Understanding that flyspeck is a disease that involves primary and secondary infections, and that inoculum is produced in reservoir hosts near orchards, provides opportunities for better management of the disease.

\section{ACKNOWLEDGMENTS}

We thank the Massachusetts Agricultural Experiment Station, United States Department of Agriculture (USDA) Federal Integrated Pest Management funds, Massachusetts Department of Agricultural Resources Integrated Pest Management, and USDA Sustainable Agriculture Research and Education funds for their support; and B. Roitberg, Simon Frasier University, for assistance with the degree-day model.

\section{LITERATURE CITED}

1. Babadoost, M., McManus, P. S., Helland, S. N., and Gleason, M. L. 2004. Evaluating a wetness-based warning system and reducedrisk fungicides to manage sooty blotch and flyspeck of apple. HortTechnology 14:51-57.

2. Baines, R. C. 1940. Pathogenicity and hosts of the fly-speck fungus of apple. (Abstr.) Phytopathology 30:2.

3. Baker, K. F., Davis, L. H., Durbin, R. D., and Snyder, W. C. 1977. Greasy blotch of carnation and flyspeck of apple- diseases caused by $Z y$ gophiala jamaicensis. Phytopathology 67:580588.

4. Baskerville, G., and Emin, P. 1969. Rapid estimation of heat accumulation from maximum and minimum temperatures. Ecology 50:514-517.

5. Bates, D. M., and Watts, D. G. 1988. Nonlinear Regression Analysis and Its Applications. Wiley, New York.

6. Batzer, J. C., Gleason, M. L., Harrington, T. C., and Tiffany, L. H. 2005. Expansion of the sooty blotch and flyspeck complex on apples based on analysis of ribosomal DNA gene sequences and morphology. Mycologia 97:12681286.

7. Brown, E. M., and Sutton, T. B. 1993. Time of infection of Gloeodes pomigena and Schizothyrium pomi on apple in North Carolina and potential control by an eradicant spray program. Plant Dis. 77:451-455.

8. Brown, E. M., and Sutton, T. B. 1995. An empirical-model for predicting the first symptoms of sooty blotch and flyspeck of apples. Plant Dis. 79:1165-1168.

9. Cooley, D. R. 1998. Integrated management of summer disease: finding the hidden target.
Proc. N. Engl. Fruit Meet. 104:92-98.

10. Cooley, D. R., Autio, W. R., and Gamble, J. W. 1991. Flyspeck and sooty blotch: New problems and new ideas. Fruit Notes 55:24-26.

11. Durbin, R. D., Davis, L. H., Snyder, W. C., and Baker, K. F. 1953. The imperfect stage of $M i-$ crothyriella rubi, cause of flyspeck of apple. Phytopathology 43:470-471.

12. Durbin, R. D., and Snyder, W. C. 1953. Ecology and hosts of flyspeck of apple in California. Phytopathology 43:586-586.

13. Hickey, K. D., Lewis, F. H., and Taylor, C. F. 1958. Time of apple fruit infection by Gloeodes pomigena and Microthyriella rubi. Phytopathology 48:462-462.

14. Johnson, E. M., and Sutton, T. B. 2000. Response of two fungi in the apple sooty blotch complex to temperature and relative humidity. Phytopathology 90:362-367.

15. Latham, A. J., and Hollingsworth, M. H. 1973. Incidence and control of sooty blotch and flyspeck on apples in Alabama. Auburn Univ. Agric. Exp. Stn. Circ. 208.

16. Lerner, S. M. 1999. Studies on the biology and epidemiology of Schizothyrium pomi, causal agent of flyspeck disease of apple. M.S. thesis, Department of Microbiology, University of Massachusetts, Amherst.

17. Nasu, H., Fujii, S., and Yokoyama, T. 1985. Zygophiala jamaicensis mason, a causal fungus of flyspeck of grape, Japanese persimmon and apple. Ann. Phytopathol. Soc. Jpn. 51:536545.

18. Nasu, H., and Kunoh, H. 1987. Distribution of Zygophiala jamaicensis in Okayama Prefecture, Japan. Trans. Mycol. Soc. Jpn. 28:209213.

19. Ocamb-Basu, C. M., and Sutton, T. B. 1988. Effects of temperature and relative-humidity on germination, growth, and sporulation of $Z y$ gophiala jamaicensis. Phytopathology 78:100103.

20. Rosenberger, D. A., Engle, C. A., and Meyer, F. W. 1996. Effects of management practices and fungicides on sooty blotch and flyspeck diseases and productivity of liberty apples. Plant Dis. 80:798-803.

21. Sutton, T. B. 1990. Sooty blotch and flyspeck. In: Compendium of Apple and Pear Diseases. A. L. Jones and H. S. Aldwinkle, eds. American Phytopathological Society Press, St. Paul, $\mathrm{MN}$.

22. Sutton, T. B.. 1990. Dispersal of conidia of Zygophiala jamaicensis in apple orchards. Plant Dis. 74:643-646.

23. Sutton, T. B., Bond, J. J., and Ocamb-Basu, C. M. 1988. Reservoir hosts of Schizothyrium pomi, cause of flyspeck of apple, in North Carolina. Plant Dis. 72:801-801.

24. Williamson, S. M., and Sutton, T. B. 2000. Sooty blotch and flyspeck of apple: Etiology, biology, and control. Plant Dis. 84:714-724. 